\title{
Journal of Science and Engineering
}

Full Paper

\section{ANALISA KUAT TEKAN BETON MENGGUNAKAN PASIR APUNG}

\author{
Abdul Gausª, Imranª, Liska Noviantia ${ }^{*}$ \\ aUniversitas Khairun, Ternate, Indonesia
}

Article history

Received

5 Januari 2018

Received in revised form

17 Pebruari 2018

Accepted

5 Mei 2018

*Corresponding author abdulgaus@unkhair.ac.id

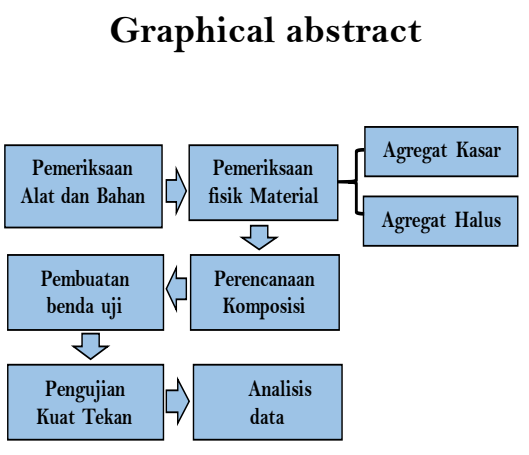

\begin{abstract}
Pumice sand is a bright colored butian type, containing foam made from glass-walled bubbles and usually referred to as silicate volcanic glass granules. This pumice sand can be used as a substitute for normal sand as fine aggregate in a mixture of concrete mix. Based on the characteristic test examination, it can be seen that in testing the characteristics of pumice sand to the specifications of normal sand in specific gravity testing and weight testing of quicksand obtained results that are smaller than the specifications of normal sand and absorption tests obtained results greater than specifications on normal sand. The results of the normal sand compressive strength at $\mathrm{BN}$ is $250.95 \mathrm{~kg} / \mathrm{cm} 2$ while the results of the floating sand concrete compressive strength on BPA is $224,965 \mathrm{~kg} / \mathrm{cm} 2$. Based on the research it can be concluded that with the same quality of concrete, the quality of K-250 is different in comparison to the compressive strength of concrete in normal sand and pumice sand concrete shows almost the same results. Therefore, more in-depth research is needed regarding the use of pumice sand instead of normal sand in a mixture of concrete mix.

Keywords: Compressive strength, normal concrete, pumice sand concrete

Abstrak

Pasir apung merupakan jenis butiran yang berwarna terang, mengandung buih yang terbuat dari gelembung berdinding gelas dan biasanya disebut juga sebagai butiran gelas vulkanik silikat. Deposit pasir apung di Maluku Utara sangat besar, jumlahnya jutaan meter kubik. Pasir apung dapat dimanfaatkan sebagai bahan pengganti pasir normal dalam campuran beton. Penelitian ini melakukan pengujian terhadap karakteristik fisik pasir apung yang meliputi, analisasi saringan, berat jenis, absorbsi dan berat isi. Pengujian SEM dan XRD dilakukan untuk mengetahui kandungan kimia dari pasir apung. Campuran beton diuji menggunakan mesin UTM untuk mengetahui kuat tekan dan tarik belah. Hasil penelitian kuat tekan pasir normal pada BN adalah $252,351 \mathrm{Kg} / \mathrm{cm}^{2}$ sedangkan hasil kuat tekan beton pasir apung pada BPA adalah $224,281 \mathrm{Kg} / \mathrm{cm}^{2}$. Berdasarkan penelitian dapat disimpulkan bahwa dengan mutu beton yang sama yaitu mutu K-250 perbedaan perbandingan kuat tekan beton pada pasir normal dan beton pasir apung menunjukkan hasil yang hampir sama. Oleh karena itu perlu dilakukan penelitian yang lebih mendalam lagi mengenai penggunaan pasir apung sebagai pengganti pasir normal dalam campuran adukan beton.
\end{abstract}

Kata kunci: Kuat tekan, beton normal, beton pasir apung

(C) 2018 Penerbit Fakultas Teknik Unkhair. All rights reserved

\subsection{PENDAHULUAN}

Perkembangan beton sangat diperlukan untuk meningkatkan bidang pembangunan. Berkambangnya pembangunan di Bidang Teknik Sipil sangat pesat dan didorong oleh perkembangan teknologi beton dan produk 
beton yang dihasilkan sangat inovatif. Beton dapat dikatakan sebagai bahan utama bangunan konstruksi di indonesia.

Kota Ternate merupakan salah satu daerah di Maluku Utara yang memiliki ketersediaan pasir, namun jika dimanfaatkan secara terus-menerus maka semakin hari jumlahnya semakin menipis oleh karena itu perlu adanya inovasi. Kota Ternate merupakan suatu daerah dengan pertumbuhan serta peningkatan mobilitas penduduk yang berkembang cukup pesat. Perkembangan wilayah pemukiman di Ternate menyebabkan meningkatnya kebutuhan akan sarana dan prasarana yang mencukupi. Penyelesaian yang diharapkan dapat menciptakan inovasi terbaru dalam penyelesaian masalah konstruksi bangunan. Dewasa ini penggunaan beton ringan merupakan alternatif yang sangat bagus sebab beton dengan mutu tinggi yang telah digunakan sebagai material dasar sejak ribuan tahun lalu digunakan untuk pengaplikasian pada konstruksi bangunan. Berat jenis beton normal sangat tinggi yaitu berkisar $2400 \mathrm{~kg} / \mathrm{m} 3$ sehingga beban mati yang dipikul akan menjadi sangat besar. Untuk mengurangi beban mati suatu struktur beton atau mengurangi sifat penghantaran panas maka perlu digunakan beton ringan menggunakan pasir apung dengan berat isi antara 500-900 kg/m3. Oleh karena itu pasir apung merupakan material yang sangat cocok dipakai dalam campuran beton ringan, sebab mampu menyerap air yang ada di permukaan dan sangat tahan terhadap suhu panas, maka selanjutnya akan diteliti perilaku geser pada balok akibat penggunaan pasir apung.

Sumber daya alam yang terdapat di Kota Tidore Kepulauan, salah satunya berupa ketersediaan pasir apung yang dapat dimanfaatkan untuk membuat beton. Berdasarkan survei yang dilakukan perlu adanya inovasi mengenai campuran beton dengan menggunakan pasir apung yang kemudian dibandingkan dengan hasil kuat tekan beton pada pasur normal. Oleh karena itu, perlu adanya suatu penelitian mendalam mengenai kaut tekan beton pada pasir apung dan dapat dipertanggungjawabkan hasil kuat tekannya.

Beberapa penelitian mengenai beton ringan yang pernah dilakukan berdasarkan studi literatur jumlah tulisan dan hasil yang telah dilakukan berdasarkan uji laboratorium maupun pengujian lapangan. Sepanjang pengetahuan penulis belum pernah dilakukan penelitian yang serupa. Kuat Tekan dan Modulus Elastisitas Beton Ringan Dengan Menggunakan Agregat Batu Apung Serta Abu Terbang Sebagai Pengganti Sebagian Semen Portland dan Superplasticizer. Penelitian ini dilakukan untuk mengetahui perilaku mekanik balok beton ringan meliputi kuat tekan dan modulus elastisitas beton ringan [9]. Pengaruh Penambahan Styrofoam Dengan Pelarut Toluena Terhadap Kuat Tekan Dan Modulus Elastisitas Beton Ringan. Penelitian ini bertujuan untuk mengetahui pengaruh penambahan Styrofoam dengan pelarut toluena terhadap kuat tekan dan modulus elastisitas beton ringan [10]. Penetrasi Dan Permeabilitas Beton Ringan. Penelitian ini dilakukan untuk mengetahui seberapa besar porositas beton ringan sebagai salah satu tolak ukur durabilitas beton, pada penelitian ini dilakukan pengujian serapan, penetrasi dan permeabilitas beton ringan. Hasil pengujian diketahui bahwa nilai serapan, penetrasi dan permeabilitas air pada beton ringan meningkat seiring dengan pertambahan nilai faktor air semen [13]. Pengaruh Penambahan Serat Seng Pada Beton Ringan Dengan Teknologi Foam Terhadap Kuat Tekan, Kuat Tarik. Dari penelitian ini dihasilkan beton ringan foam berserat seng termaksud beton ringan (berat jenis < $1900 \mathrm{~km} / \mathrm{m} 3)$. Berdasarkan hasil kuat tekan beton ringan foam serat aluminium sudah dapat dikategorikan beton struktural [4]. Perilaku Geser pada keadaan Layan dan Batas Balok Beton Bertulang Berlubang Memanjang, penelitian ini pemanfaatan pengurangan bobot beton dengan meneliti perilaku geser balok pada kondidi batas [11]. Pemanfaatan Superplasticizer Beton Ringan Beragregat Limbah Botol Plastik Jenis Poly Ethylene Terephthalate (PET) Penelitian ini mencari berapakah perbandingan campuran semen, agregat kasar, halus dan air beserta zat penambah admixture [7]. Kajian kuat tekan beton dengan perbandingan berat untuk produksi beton massa menggunakan agregat kasar batu pecah merapi (studi kasus pada proyek pembangunan sabo dam, penelitian ini bertujuan untuk mengkaji kuat tekan beton K250 dengan perbandingan berat (PB) dan perbandingan volume (PV) menggunakan agregat kasar batu pecah merapi sebagai percobaan pendahuluan (trial mix) pada proyek pembangunan Sabo dam [6]. Pencampuran beton perlu memperhatikan bahan dan praktek beton, perlu dilakukan adanya kombinasi agregat untuk memperoleh berat jenis yang lebih rendah dari berat jenis beton normal [5], tipe beton ringan dan karakteristiknya dapat dilihat pada tabel 1. Mencampurkan tanah liat ke dalam campuran beton ringan meningkatkan sifat mekanik beton ringan sama halnya seperti menambahkan

01:05 (2018) 31-40 | http://ejournal.unkhair.ac.id/index.php/josae | ISSN 2621-3435| 
limbah polietilen. Tanah liat mempunyai sifat seperti agregat plastik dan memungkinkan untuk terjadinya proses hidrasi semen yang bisa menurunkan penyerapan pada beton ringan [8]. Kekuatan mutu beton ringan pada umur 28 hari dapat di prediksi dengan tingkat kesalahan rata-rata dan standar deviasi minimum dengan menggunakan model grafik vector [1].

Table 1. Berbabai jenis beton ringan dan karakteristiknya

\begin{tabular}{|c|c|c|c|c|c|}
\hline \multirow[t]{3}{*}{ No } & \multirow{3}{*}{$\begin{array}{l}\text { Tipe beton } \\
\text { ringan }\end{array}$} & Berat jenis & Kuat & Penyusutan & Konduktivitas \\
\hline & & di udara & desak & Kering & Suhu \\
\hline & & $\left(\mathrm{kg} / \mathrm{m}^{3}\right)$ & $\left(\mathrm{N} / \mathrm{mm}^{2}\right)$ & $(\%)$ & $\left(\mathrm{W} / \mathrm{M}^{\circ} \mathrm{C}\right)$ \\
\hline 1 & $\begin{array}{l}\text { Tepung abu bakar } \\
\text { yang dikeraskan } \\
\text { (Lytag) }\end{array}$ & $1360-1760$ & $14-42$ & $\mathrm{O}, 04-0,07$ & $0,32-0,91$ \\
\hline 2 & $\begin{array}{l}\text { Batu tulis atau } \\
\text { tanah liat yang } \\
\text { dikembangkan } \\
\text { (Agli \& Leca) }\end{array}$ & $1360-1840$ & $14-42$ & $\mathrm{O}, 04-0,07$ & $0,24-0,91$ \\
\hline 3 & $\begin{array}{l}\text { Busa arang } \\
\text { (Foamed Slag) }\end{array}$ & $1680-2080$ & $10,5-42$ & O,03-0,07 & $0,24-0,93$ \\
\hline 4 & Batu apung & $720-1440$ & $2-14$ & 0,04-0,08 & $0,21-0,6$ \\
\hline 5 & $\begin{array}{l}\text { Clinker (butiran } \\
\text { yang mengeras) }\end{array}$ & $1040-960$ & $2-7$ & $0,04-0,18$ & $0,35-0,67$ \\
\hline 6 & $\begin{array}{lr}\text { Adukan } & \text { semen } \\
\text { yang } & \text { dicampur } \\
\text { dengan } & \text { udara } \\
\text { (aerated) } & \end{array}$ & $400-960$ & $1,4-4,9$ & 0,02-0,03 & $0,10-0,22$ \\
\hline 7 & $\begin{array}{l}\text { Beton padat yang } \\
\text { berisis kerikil atau } \\
\text { batu pecah }\end{array}$ & $2240-2480$ & $14-70$ & $0,03-0,05$ & $1,40-1,80$ \\
\hline
\end{tabular}

\subsection{METODOLOGI}

Pengujian ini dilakukan di Laboratorium struktur dan bahan fakultas teknik program studi teknik sipil Universitas Khairun. Secara umum, desain benda uji dalam penelitian ini adalah sebagai berikut:

1. Silinder ukuran timggi $30 \mathrm{~cm}$ dengan diameter $15 \mathrm{~cm}$

2. Menggunakan agregat halus pasir biasa sebagai pasir pembanding atau pasir control

3. Menggunakan agregat halus pasir apung

Alat yang digunakan untuk menguji kuat tekan silinder adalah Compression Machine $2000 \mathrm{kN}$. Pengujian ini berdasarkan pada spesifikasi standar [2] dengan menggunakan rumus sebagai berikut:

$$
f^{\prime} c=\frac{P}{A} \text {. }
$$

Dengan:

$$
\begin{aligned}
& f^{\prime} \mathrm{c}=\text { Kuat tekan }\left(\mathrm{kg} / \mathrm{cm}^{2}\right) \\
& \mathrm{P}=\text { Beban maksimum }(\mathrm{kg})
\end{aligned}
$$




$$
\mathrm{A}=\operatorname{Luas}\left(\mathrm{cm}^{2}\right)
$$

Pengujian ini menggunakan benda uji sebanyak 2 buah silinder dengan agregat halus yang berbeda namun menggunakan agrega kasar yang sama, dengan ukuran tinggi $30 \mathrm{~cm}$ dan diameter $15 \mathrm{~cm}$ yang ditunjukkan pada gambar 1 dan variasi benda uji dapat dilihat pada tabel 2.

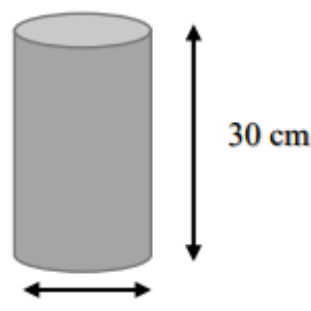

$15 \mathrm{~cm}$

Gambar 1 Benda uji pengujian kuat tekan beton

Tabel 2 Variasi benda uji

\begin{tabular}{llll}
\hline Benda uji & FAS & $\begin{array}{l}\text { Luas } \\
(\mathbf{c m} 2)\end{array}$ & $\begin{array}{l}\text { Jumlah } \\
\text { sampel }\end{array}$ \\
\hline BN & 0,35 & 176,625 & 5 \\
\hline BP & 0,35 & 176,625 & 5 \\
\hline
\end{tabular}

\subsection{HASIL DAN PEMBAHASAN}

\subsection{Karakteristik Agregat Halus}

Hasil dari pengujian karakteristik agregat yaitu pada pasir normal dan pasir apung dapat dilihat pada tabel 3. Pasir normal yang dijadikan sebagai pembanding untuk pasir apung juga dilakukan pengujian karakteristik agar dapat diketahui selisih dari hasil pemeriksaan pada kedua agrega tersebut berdasarkan pada spesifikasi pengujian karakteristik agregat halus menurut SNI [3], untuk mengetahui spesifikasi pengujian untuk agregat halus. Pada gambar 2. menunjukkan bahwa gambar gradasi agregat halus pada pasir dan gradasi agregat halus pada pasir apung.

Tabel 3. karakteristik pasir normal dan pasir apung

\begin{tabular}{llcc}
\hline No & Jenis Pengujian & \multicolumn{2}{c}{ Hasil Pemeriksaan } \\
\cline { 2 - 4 } & & Pasir & Pasir Apung \\
\hline $\mathbf{1}$ & Kadar lumpur & $4,5 \%$ & $0,53 \%$ \\
\hline $\mathbf{2}$ & Berat jenis & 2,68 & 0,76 \\
\cline { 2 - 4 } & Berat jenis kering (bulk specificgravity) & 2,7 & 0,63 \\
\cline { 2 - 4 } & $\begin{array}{l}\text { Berat jenis kering permukaan jenuh } \\
\text { (saturated surface dry) }\end{array}$ & & 0,82 \\
\cline { 2 - 4 } & Berat jenis semu (apparent specific gravity) & 2,75 & $14,98 \%$ \\
\hline $\mathbf{3}$ & Berat volume & $1,5 \%$ & 0,71 \\
\cline { 2 - 4 } & Kondisi padat & 1,71 & 0,66 \\
\cline { 2 - 4 } & Kondisi lepas & 1,6 & $2,75 \%$ \\
\hline $\mathbf{4}$ & Modulus halus berbutir (MHB) & $1,73 \%$ & \\
\hline
\end{tabular}


Berdasarkan pada tabel 3. dapat diketahui bahwa selisih kadar lumpur antara pasir normal dan pasir apung adalah 3,97\%, selisih berat jenis kering antara pasir normal dan pasir apung adalah 1,92, selisih berat jenis kering permukaan jenuh antara pasir normal dan pasir apung adalah 2,07, selisih berat jenis semu antara pasir normal dan pasir apung adalah 1,93, selisih penyerapan antara pasir normal dan pasir apung adalah 13,48\%, selisih berat volume pada saat kondisi padat antara pasir normal dan pasir apung adalah 1, selisih berat volume pada saat kondisi lepas antara pasir normal dan pasir apung adalah 0,94 dan selisih modulus halus berbutir antara pasir normal dan pasir apung adalah 1,02. Pada tabel 3. Pengujian pada berat volume pada pasir apung lebih ringan daripada spesifikasi pasir normal pada SNI, dengan kata lain pasir apung tergolong beton ringan dan dapat digunakan dalam campuran adukan beton. Pada pengujian penyerapan yang ditunjukkan oleh tabel 3. diketahui bahwa penyerapan yang terjadi pada pasir apung sangat meningkat dan memiliki selisih yang sangat jauh dari penyerapan pada pasir normal, hal tersebut disebabkab karena kemampuan pasir apung yang memiliki daya serap air yang sangat besar.

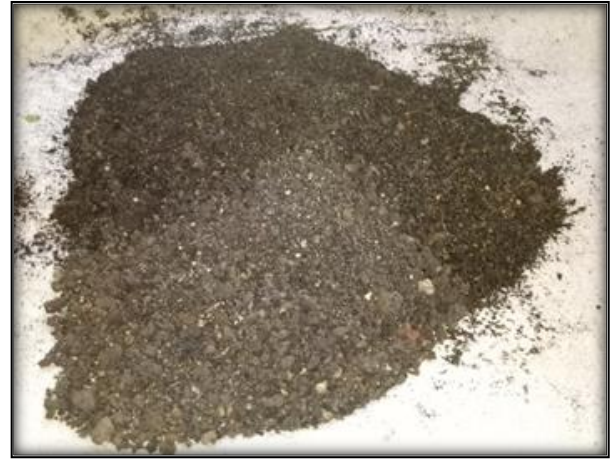

a. Pasir normal

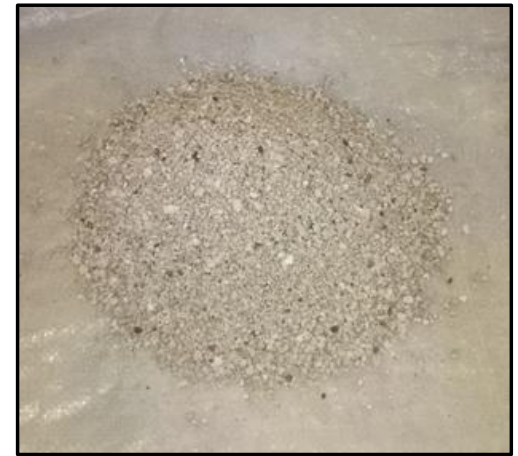

b. Pasir apung

Gambar 2. (a) Pasir normal (b) Pasir apung

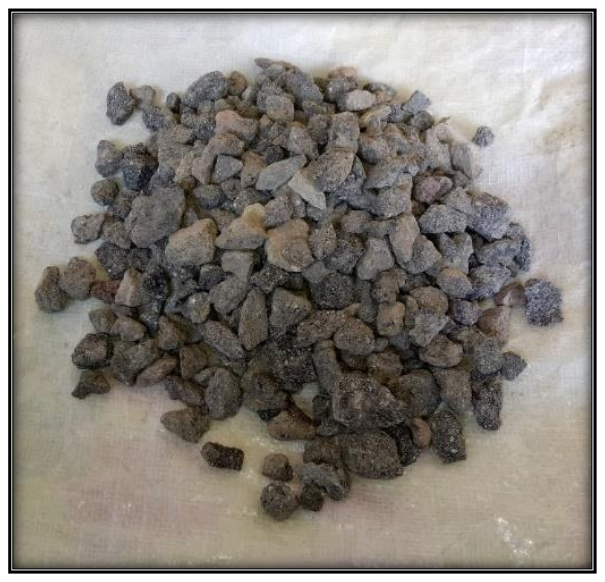

Gambar 3. Visualisasi agregat kasar

Gambar 2. Menunjukkan bahwa pasir normal dan pasir apung dari segi tekstur tidak jauh berbeda, ditinjau dari segi warna agregat, pasir apung memiliki warna yang lebih terang dibandingkan dengan warna agregat halus pada pasir normal.

Pengujian agregat ini dilakukan di laboratorium struktur dan bahan jurusan teknik sipil Universitas Khairun Ternate. dalam penelitian ini agregat halus yang digunakan ada dua macam yaitu: agregat halus pasir normal yang berasal dari (quarry) Kelurahan Kaluma, Ternate. Agregat halus lainnya yang digunakan dalam penelitian ini adalah pasir apung yang berasal dari (quarry) Kelurahan Rumbune, Tidore. Pada penelitian ini digunakan dua 
jenis agregat halus karena akan dilakukan perbandingan pengujian karakteristik antara beton normal dengan beton ringan. Hasil pengujian agregat ini berdasarkan pada standar SNI. Adapun hasil pengujian tersebut disajikan dalam tabel 3.

Pengujian ini dilakukan untuk mengetahui karakteristik agregat halus yaitu pasir normal merupakan agregat halus yang berasal (quarry) dari Kelurahan Tubo, Kota Ternate dan agregat halus pasir apung yang berasal dari Tidore Kempulauan, yang kemudian disaring hingga didapatkan gradasi pasir (lolos saringan No. 3/8") selanjutnya dilakukan pengujian di Laboratorium Struktur dan Bahan Fakultas Teknik Universitas Khairun Ternate. Pemeriksaan karakteristik pada pasir normal dan pasir apung ini merupakan pemeriksaan karakteristik yang dilakukan dengan perlakuan yang sama pada agregat halus pada umumnya. Pada pengujian karakteristik pasir normal ini dibahas mengenai standar parameter (spesifikasi) yang harus dipenuhi oleh agregat halus (pasir normal) untuk keperluan pengecekan hasil pengujian agregat halus (pasir apung dan pasir normal) yang dilakukan di Laboratorium. Pengujian Karakteristik pada Pasir Normal (pasir quarry Kalumata, Ternate dilakukan untuk dijadikan sebagai perbandingan terhadap pengujian karakteristik yang telah dilakukan pada pasir apung. Adapun hasil pengujian karakteristik pada pasir normal dapat dilihat pada tabel 3.

Table-2. Chemical elements comparison

\begin{tabular}{lllllll}
\hline Agregat Halus & Al & Si & K & Ca & Fe & Ti \\
\hline Pasir Apung & $10 \%$ & $58,9 \%$ & $9,78 \%$ & $8,82 \%$ & $10,1 \%$ & \\
\hline Pasir normal & & $28,7 \%$ & $2,96 \%$ & $17,1 \%$ & $44,5 \%$ & $2,18 \%$ \\
\hline
\end{tabular}

Table 2 menunjukkan komposisi dari unsur kimia yang dominan terhadap 2(dua) jenis agregat halus hasil pengujian XRF. Agregat halus pumice memiliki kandungan unsur kimia silika ( $\mathrm{Si}$ ) yang lebih dominan dari unsur lainnya, bahkan hampir mencapai 6(enam) kali lebih banyak dari unsur kimia besi (Fe) yang pada agregat halus pasir normal merupakan unsur kimia yang paling banyak dikandung. Selain itu agregat halus pasir apung mengandung unsur alumunium ( $\mathrm{Al}$ ) yang cukup banyak dan tidak terkandung pada agregat halus pasir normal, sebaliknya ageregat halus pumice tidak mengandung unsur titanium (Ti) yang ada pada agregat halus pasir normal. Kontradiksi antara agregat halus pasir apung dan pasir normal pada unsur kimia yang dikandung menyebabkan sifat-sifat fisik dari kedua agregat halus tersebut menjadi berbeda.

\subsection{Pengujian Kuat Tekan Beton}

Kuat tekan beton adalah besarnya beban per satuan luas, yang menyebabkan benda uji beton hancur bila dibebani gaya tekan tertentu yang dihasilkan oleh mesin tekan. Kuat tekan beton merupakan sifat terpenting dalam kualitas beton dibanding dengan sifat-sifat lain. Kekuatan tekan beton ditentukan oleh pengaturan dari perbandingan semen, agregat kasar dan halus, air. Perbandingan dari air semen, semakin tinggi kekuatan tekannya. Suatu julah tertentu air diperlukan untuk memberikan aksi kimiawi dalam pengerasan beton, kelebihan air meningkatkan kemampuan pekerjaan akan tetapi menurunkan kekuatan [11].

Untuk pengujian kuat tekan beton yang dilakukan di Laboratorium Struktur dan Bahan Teknik Sipil Universitas Khairun Ternate. Sampel yang digunakan dalam pengujian ini ada dua macam yaitu mutu beton K250 untuk beton normal dan mutu beton K250 untuk beton pasir apung kemudian kedua sampel tersebut dilakukan mix design dengan FAS yang sama, yaitu FAS 0,35. Tabel 4 menunjukkan bahwa komposisi campuran untuk mutu beton K250 pada sampel beton normal sebagai berikut:

Pada tabel 4 menunjukkan hasil perbandingan faktor air semen pada beton normal yaitu 0,35 dengan semen $627,62 \mathrm{~kg} / \mathrm{m} 3$, pasir sebanyak $381,39 \mathrm{~kg} / \mathrm{m} 3$ dengan batu pecah sebanyak $621,343 \mathrm{~kg} / \mathrm{m} 3$. Nilai yang diperoleh pada tabel 4 ini merupakan nilai yang diperoleh berdasarkan pengujian karakteristik dengan penggabungan agregat yang berdasarkan pada hasil barchart penggabungan agregat antara pasir normal dan agregat kasar (batu pecah/split), adapun hasil yang diperoleh dari barchart penggsbungan agregat tersebut adalah hasilyang 
diperoleh dengan menggunakan cara tryal and error, begitupun dengan nilai barchart yang diperoleh dari penggabungan agregat antara pasir apung dengan agregta kasar.

Tabel 4 Pebandingan air semen pada beton normal

\begin{tabular}{lcc}
\hline Bahan Beton & Berat $\left(\mathbf{k g} / \mathbf{m}^{\mathbf{s}}\right)$ & Rasio Terhadap Semen \\
\hline Semen & 627,62 & 1,00 \\
\hline Pasir & 381,39 & 0,61 \\
\hline Batu Pecah & 621,343 & 0,99 \\
\hline Air & 219,67 & 0,35
\end{tabular}

Pada beton pasir apung dengan perbandingan air faktor air semen yang sama yaitu 0,35 dengan semen 585,71 $\mathrm{kg} / \mathrm{m}^{3}$, pasir apung sebanyak 402,91 kg/m³ dengan batu pecah sebanyak $656,38 \mathrm{~kg} / \mathrm{m}^{3}$. Agregat kasar yang digunakan pada campuran beton normal dan pada beton pasir apung adalah agregatkasar yang sama dari quarry yang sama. Adapun gradasi agregat kasar yangdigunakan pada campuran beton normal dan beton pasir apung ditunjukkan pada gambar 3 sedangkan komposisi perbandingan air semen pada campuran mutu beton K250 untuk sampel beton pasir apung dapat dilihat pada tabel 5 sebagai berikut:

Tabel 5 Pebandingan air semen pada beton pasir apung

\begin{tabular}{lcc}
\hline Bahan Beton & Berat $\left(\mathbf{k g} / \mathbf{m}^{\mathbf{s}}\right)$ & Rasio Terhadap Semen \\
\hline Semen & 585,71 & 1,00 \\
\hline Pasir apung & 402,91 & 0,69 \\
\hline Batu Pecah & 656,38 & 1,12 \\
\hline Air & 205 & 0,35
\end{tabular}

Pada saat melakukan pengujian kuat tekan beton maka hal pertama yang akan dilakukan adalah pemeriksaan alat dan bahan sebagai berikut:

- Cetakan silinder, diameter $152 \mathrm{~mm}$, tinggi $305 \mathrm{~mm}$;

- Tongkat pemadat, diameter $16 \mathrm{~mm}$, panjang $600 \mathrm{~mm}$, dengan ujung dibulatkan, dibuat dari baja yang bersih dan bebas karat;

- Mesin pengaduk atau bak pengaduk beton kedap air;

- Timbangan dengan ketelitian 0,3\% dari berat contoh;

- Mesin tekan, kapasitas sesuai kebutuhan;

- Satu set alat pelapis (capping);

- Peralatan tambahan : ember, sekop, sendok, sendok perata, dan talam;

- Satu set alat pemeriksa slump;

- Satu set alat pemeriksaan berat isi beton. 
Setelah alat dan bahan pengujian telah disiapkan maka hal selanjutnya yang perlu dilakukan adalah melakukan pemeriksaan fisik terhadap material yang akan yang akan dijadikan sebagai bahan campuran pada beton yaitu: pemeriksaan fisik pada agregat kasar dan agregat halus, adapun pemeriksaan fisik terhadap material ini harus memenuhi spsesifikasi pengujian agregat yang berdasarkan pada spesifikasi Standar Nasional Indonesia (SNI). Setelah melakukan pemeriksaan fisik material baik pada agregat kasar maupun agregat halus maka selanjutnya adalah membuat perencanaan komposisi campuran beton, kemudian tahap selanjutnya adalah pembuatan benda uji, berikut ini adalah tata cara pembuatan benda uji pada beton:

- Benda uji dibuat dari beton segar yang mewakili campuran beton;

- Isilah cetakan dengan adukan beton dalam 3 lapis, tiap-tiap lapis dipadatkan dengan 25 kali tusukan secara merata. Pada saat melakukan pemadatan lapisan pertama, tongkat pemadat tidak boleh mengenai dasar cetakan, pada saat pemadatan lapisan kedua serta ketiga tongkat pemadat boleh masuk kira-kira 25,4 mm kedalam lapisan dibawahnya;

- Setelah selesai melakukan pemadatan, ketuklah sisi cetakan perlahan-lahan sampai rongga bekas tusukan tertutup, ratakan permukaan beton dan tutuplah segera dengan bahan yang kedap air serta tahan karat, kemudian biarkan beton dalam cetakan selama 24 jam dan letakkan pada tempat yang bebas dari getaran.

- Setelah 24 jam, bukalah cetakan dan keluarkan benda uji, untuk perencanaan campuran beton, rendamlah benda uji dalam bak perndam berisi air pada temperatur $25^{\circ} \mathrm{C}$ disebutkan untuk pematangan (curing), selama waktu yang dikehendaki, untuk pengendalian mutu beton pada pelaksanaan pembetonan, pematangan (curing) disesuaikan dengan persyaratan.

Kemudian tahap selanjutnya adalah melakukan pengujian kuat tekan beton, berikut ini adalah tahap yang harus diikuti dalam pengujian kuat tekan pada beton:

- Ambilah benda uji yang akan ditentukan kekuatan tekannya dari bak perendam, kemudian bersihkan dari kotoran yang menempel dengan kain lembab;

- Tentukan berat dengan alat timbang benda uji

- Lapisilah (capping) permukaan atas dan bawah benda uji dengan mortar belerang seperti pada gambar 5, hal tersebut dilakukan agar permukaan benda uji menjadi halus dan rata serta memudahkan dalam proses pembebanan pada benda uji hingga menjadi hancur.

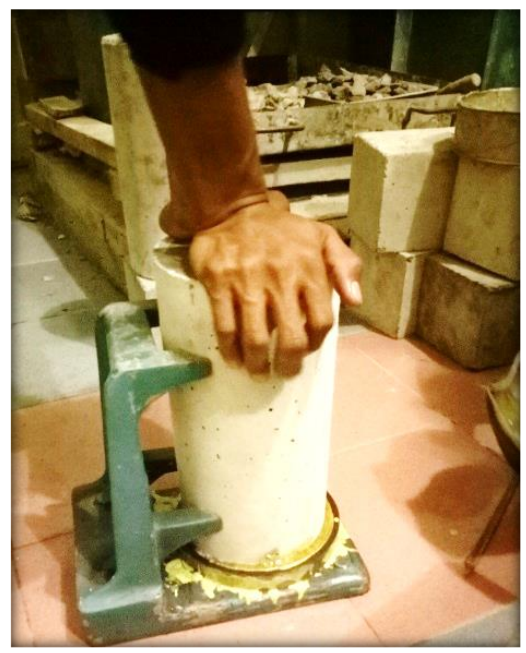

Gambar 5. Proses capping beton

- Letakkan benda uji pada mesin tekan secara centris;

- Jalankan mesin tekan dengan penambahan beban yang konstan berkisar antara 2 sampai $4 \mathrm{~kg} / \mathrm{cm}^{2}$ per detik 
- Lakukan pembebanan sampai uji menjadi hancur dan catatlah beban maksimum yang terjadi selama pemeriksaan benda uji.

Setelah tahap pembuatan benda uji beton, maka tahap akhir yang dilakukan adalah tahap analis data, yaitu menganalisis hasil kuat tekan yang telah diperoleh pada pengujian yang telah dilakukan di laboratorium.

Pengujian kuat tekan beton dilakukan pada saat usia beton telah mencapai 28 hari. Hasil pengujian kuat tekan beton normal dan beton pasir apung ditunjukkan gambar 6 .

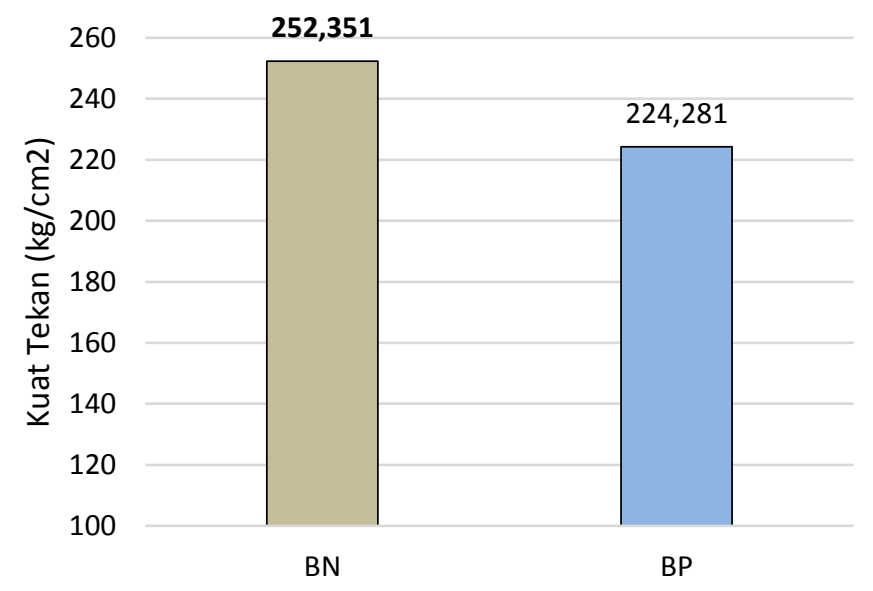

Gambar 6. Kuat tekan beton menggunakan pasir apung

Pengujian kuat tekan pada silinder ini menggunakan dua sampel dengan agregat halus yang berbeda, yaitu beton yang menggunakan pasir normal dan beton yang menggunakan pasir apung. Pengujian kuat tekan pada beton normal dan beton pasir apung ini dilakukan dengan menggunakan variasi Faktor Air Semen (FAS) yang sama yaitu FAS 0,35. Berdasarkan hasil pengujian kuat tekan maka diperoleh hasil kuat tekan pada beton normal adalah $252,351 \mathrm{~kg} / \mathrm{cm}^{2}$ dan hasil pengujian kuat tekan pada beton pasir apung adalah $224,281 \mathrm{~kg} / \mathrm{cm}^{2}$. Adapun mutu beton pada campuran beton normal ini adalah mutu beton yang sama dengan campuran dengan agregat halus yang menggunakan pasir apung yaitu mutu beton K-250.

\subsection{KESIMPULAN}

Berdasarkan hasil penelitian maka dapat disimpulkan sebagai berikut:

1. Hasil pengujian pada kuat tekan pada beton yaitu antara beton pasir normnal dan pasir apung memiliki kuat tekan yang tidak jauh berbeda yaitu hasil penelitian kuat tekan beton pasir normal pada BN adalah 252,351 $\mathrm{kg} / \mathrm{cm}^{2}$ dan Hasil penelitian kuat tekan beton pasir apung pada BP adalah $224,281 \mathrm{~kg} / \mathrm{cm}^{2}$ dan selisih kuat tekan kedua sampel tersebut adalah $28,07 \mathrm{~kg} / \mathrm{cm}^{2}$.

2. Penggunaan pasir apung sebagai bahan adukan beton tidak mempengaruhi mutu kuat tekan pada beton.

\section{Ucapan Terima Kasih}

Penelitian ini merupakan bagian penelitian dari Penggunaan Pasir Apung Sebagai Material Dasar Pembentuk Precast Beton Ringan untuk Penggunaan Konstruksi Drainase dan Perkerasan Kaku yang dibiayai oleh Dikti dengan kontrak nomor: 025/E3/2017 tanggal 6 Januari 2017 dan surat perjanjian penugasan nomor: 050/PENPDUPT/PL/2018 dan terima kasih kepada Liska Novianti mahasiswi teknik sipil universitas khairun yang telah mengambil sebagian dari topik riset ini sebagai bagian dari skripsinya dan membantu dalam penelitian. 


\section{Daftar Pustaka}

[1] Abbas M. A., Suhad M. A., 2017. Modelling the strength of lightweight foamed concrete using support vector machine (SVM). Case Studies in Construction Materials. Volume 6, pp. 8-15.

[2] BSNI, Metode Pengujian Kuat Tekan Beton (SNI 03-2847-2002), Jakarta, 2002.

$[3]$ BSNI, Metode Pengujian Analisa Saringan Agregat Halus dan Kasar (SNI 03-1968-1990), Jakarta, 1990. Gunawan, P., Prayitno, S., Majid, A,I.A., Pengaruh Penambahan Serat Seng pada Beton Ringan dengan Teknologi Foam Terhadap Kuat Tekan, Kuat Tarik dan Modulus Elastisitas, Konferensi Nasional Teknik Sipil, 2013.

Murdock, L.J., et.al., 1986, Bahan dan Praktek Beton, edisi ke-4 -, Erlangga, Jakarta, 1986.

Pratikto, Pemanfaatan Superplastiicizer Beton Ringan Beragregat Limbah Botol Plastik jenis Poly Ethylene Terephthalate (PET), Poli Teknologi Vol, 10 No. 1, 2011.

[7] Risdiyanto, Y., Kajian Kuat Tekan Beton dengan perbandingan berat untuk produksi beton massa menggunakan agregat kasar batu pecah merapi (studi kasus pada proyek pembangunan sabo dam), Teknik sipil, Universitas Negeri Yogyakarta, 2013.

[8] Rumsys D, Bacinskasa D., Spudulisa E., 2017. Meskenas A. Comparison of Material Properties of Lightweight Concrete with Recycled Polyethylene and Expanded Clay Aggregates. Procedia Engineering, Volume 172, pp. 937-944

[9] Salain, I., Kuat Tekan dan Modulus Elastisitas Beton Ringan dengan Menggunakan Agregat Batu Apung serta Abu Terbang sebagai Pengganti Sebagian Semen Portland dan Superplasticizer, Prosiding Seminar Nasional Teknik Sipil 1, 2015, 3-7.

[10] Simamora, N., Harahap, M, Pengaruh Penambahan Stryfoam dengan Pelarut Toluena terhadap Kuat Tekan dan Modulus Elastisitas Beton Ringan, Jurnal Einstein, 2015, 15-22.

[11] Supriyadi, B., dkk, Perilaku Geser pada keadaan Layan dan Batas Balok Beton Bertulang Berlubang Memanjang, Jurnal Ilmiah Semesta Teknika, 2010, 145-154.

Wang., Salmon., Pengujian Kuat Tekan pada Beton, Jakarta, 1990.

[13] Widyawati, R., Serapan, Penetrasi, dan Permeabilitas Beton Ringan, Seminar Nasional Sains dan Teknologi - IV, Naskah Publikasi Bandar Lampung, 2011, 29-33. 